\title{
Analysis of Knowledge, Implementation and Monitoring of K3 on Occupational Health and Safety Management System (SMK3) at Pt. Mujur Lestari Labuhan Batu Selatan
}

\author{
Hotbona Novandi Tambunan', Nazaruddin², Isfenti Sadalia² \\ ${ }^{1,2}$ Master of Management Study Program on Postgraduate School of University of Sumatera Utara, Indonesia.
}

Corresponding Author: Hotbona Novandi Tambunan

\section{ABSTRACT}

Occupational Health and Safety (K3) is aimed as an effort to create a workplace that is safe, healthy, free from environmental pollution, so that it can reduce and or be free from work accidents and occupational diseases and can have an impact on increasing work efficiency and productivity. The need for implementation and Monitoring of the Occupational Health and Safety Management System at PT. Mujur Lestari must have a good corporate culture and be able to contribute to SMK3. For that PT. Mujur Lestari makes implementation and monitoring to minimize the risk of work accidents for employees. The sample used in this study were employees of PT. Mujur Lestari, totaling 81 people. The data collection method used a questionnaire while the analytical method used was multivariate analysis. The results showed that there was an influence between knowledge on the Occupational Health and Safety Management System (SMK3) at PT. Mujur Lestari with a tcount greater than ttable, the effect of applying the Occupational Health and Safety Management System (SMK3) with a tcount greater than ttable, the effect of Monitoring on the Occupational Health and Safety Management System (SMK3) with a greater tcount from ttable and there is no relationship between the implementation and Monitoring of the Occupational Safety and Health Management System (SMK3). The conclusion shows that the knowledge variable has a positive and significant effect on the Occupational Safety and Health Management System (SMK3), the application variable has a
\end{abstract}

positive and significant impact on the Occupational Safety and Health Management System (SMK3) and the Monitoring variable has a positive and significant effect on the Occupational Safety and Health Management System. (SMK3).

Keywords: Occupational Health and Safety (K3), Occupational Health and Safety Management System (SMK3)

\section{BACKGROUND}

An employee in carrying out his obligations must also get his rights in work such as protection in doing work, but in reality what is currently the world of corporate work, employees in the protection he work does not match what he aspires to, it can be said that in work employees get very much Potential work hazards result in accidents that can be dangerous when employees work. Based on the case above, it can be said that employee protection carried out by the company to reduce work accidents is a management system in which there is a regulation for employees in reducing work accidents and companies can avoid losses at work. The regulation is a management system that must be implemented in a company, namely the Occupational Safety and Health Management System (SMK3), (Rini, 2013).

PT.Mujur Lestari has applied the SMK3 system around 2015, in line with the requirement for all palm oil organizations or 
companies to implement Indonesian Sustainable Palm Oil (ISPO) as regulated in the Minister of Agriculture/11-2015 namely "Indonesian Sustainable Palm Oil Certification System" or "Indonesian Sustainable Palm Oil Certification System" (ISPO). One of the principles in the ISPO is regarding the safety and health of employees. Through Ministry of Agriculture No. 11 of 2015, the company compiled a comprehensive SMK3 policy, where the guideline is PP No. 50 in 2012. The company has received an ISPO certificate in 2019, actually the SMK3 concept is going well at PT Mujur Lestari, but work accidents still often occur.

Table 1. Number of Accident at PT. Mujur Lestari on 20162019

\begin{tabular}{|l|l|l|l|}
\hline \multirow{4}{*}{ Tahun } & \multicolumn{3}{|l|}{ Number of Accident } \\
\cline { 2 - 4 } & $\begin{array}{l}\text { Near Miss } \\
\text { (Almost } \\
\text { Happened) }\end{array}$ & $\begin{array}{l}\text { Minor Injury } \\
\text { (Without Loss } \\
\text { of Work Hours) }\end{array}$ & $\begin{array}{l}\text { Accident } \\
\text { (Loss } \\
\text { Working } \\
\text { Hours) }\end{array}$ \\
\hline 2016 & 9 & 12 & 3 \\
\hline 2017 & 7 & 5 & 4 \\
\hline 2018 & 4 & 7 & 3 \\
\hline 2019 & 6 & 8 & 4 \\
\hline
\end{tabular}

Based on the data obtained above, it is necessary to have $\mathrm{K} 3$ Activities, which aim to create a comfortable, healthy and free work area from area pollution that can or can reduce work accidents, so that employees at work can increase their income and work results. Work accidents that are caused are not individual/group and material for employees and industrial owners, but can disrupt the production process evenly, disturb the area and can have an impact on residents (Lusia Salmawati, 2015). Implementation or implementation is an implementation of the system that occurs by carrying out the program when the program is implemented and can make changes to decisions so that operational patterns occur so that these changes can be achieved when ratified, with reference to the work in the company's output that has been decided. (Mulyadi, 2015).

In addition to implementation, Monitoring is also very necessary because Monitoring is a result of the vision of all organizations that these activities are carried out according to plan. against the monitoring plan in order to see the weaknesses or errors so that they are corrected and to prevent them from happening again.

\section{Knowledge Dimensions and Indicators in K3}

Knowledge in $\mathrm{K} 3$ is the output of an event experienced by individuals or groups performed through the human senses to a specific location and processing can occur in the senses contained in the human senses, namely the senses of sight, hearing, smell, and taste through the skin (Priyanti, 2011).

Knowledge in $\mathrm{K} 3$ is the first step in the work determination procedure which is an attempt to make early prevention of K3 hazards when working in the company (Robbins, 2006). The indicators for measuring employee knowledge in K3 are:

a. Quality of work is the thinking and measurement of employees about the way they work and the results obtained in the attitude of workers at work.

b. The quantity of work that is the result of the total in the results which consists of the number of work activities completed.

c. Punctuality is the beginning of an activity that must be completed as soon as possible in terms of cooperation in order to get results by maximizing the available time.

d. Effectiveness is the extent to which the use of organizational resources (manpower, money, technology, raw materials) is maximized with the intention of increasing the results of each unit in the use of resources.

e. Independence is the level of an employee who will be able to carry out his work functions without asking for help, guidance from other people or supervisors.

f. Work commitment is a level where employees have a commitment to work with the agency and employee responsibilities to the office. 


\section{Dimensions and Implementation Indicators in $\mathrm{K3}$}

Companies must pay attention to the implementation of $\mathrm{K} 3$ implementation at work, can minimize unwanted things regarding the risk of work accidents that result in losses to the company. Based on the Ministry of Manpower Rule 5/1996 regarding SMK3, that article explains what companies must do, namely:

a. Companies must establish policies for implementing $\mathrm{K} 3$ and employees must be trained so that there is a commitment to implementing $\mathrm{OSH}$.

b. The company plans to make regulations, targets and missions that are effective in implementing K3.

c. Implementation of the company's SMK3 when the K3 policy must be implemented effectively by increasing the capacity or additional regulations needed by the company in achieving the policies, targets and objectives of occupational safety and health;

d. Companies in the implementation of K3 must continue to measure, monitor and always evaluate the implementation of $\mathrm{K} 3$ and carry out revision actions and prevention of work accidents.

e. K3 in the company must be reviewed in a measurable manner in order to always improve the implementation of SMK3 within the Company.

Policies on the implementation of SMK3 must be made, ratified and signed by the owner of the company in which the goals and objectives must be clearly stated, socialized to workers and properly archived and always reviewed regularly. Regarding the provisions of Article 5, it is explained that every company is obliged to implement/apply SMK3 in the company if there are 100 workers in the company and the work has a dangerous risk.

\section{K3 Monitoring}

K3 Monitoring is an implementation of work in the field that must be monitored against the implementation that should occur so that the work is appropriate or not carried out in the field of work (Anggraini, 2012). According to Murhaini (2014) it can be said that Monitoring consists of an assessment of a processing that can be measured so that it can be directly verified validly.

Monitoring is the practice of working in order to achieve the vision and mission of the company and company management. That is, with regard to thinking and making a program of activities that have been planned. Planning and monitoring practices have a parallel relationship in achieving organizational goals (Yahya, 2006).

\section{Occupational Health and Safety Management System (SMK3)}

Understanding this system is a regulation/system in which it consists of structure, planning, implementation responsibilities, procedural or HR processes when it is used for development, implementation, achievement, review and maintenance of policies in the context of controlling K3 itself/related work accidents for the purpose of useful occurrence, safe, efficient and productive work location/ place.

According to (Setyoko, 2017) the Occupational Health and Safety Management System is a part system which includes organizational structure, planning, responsibilities, implementation, procedures, processes and resources needed for the development of implementation, achievement, assessment and maintenance of occupational safety and health. (K3).

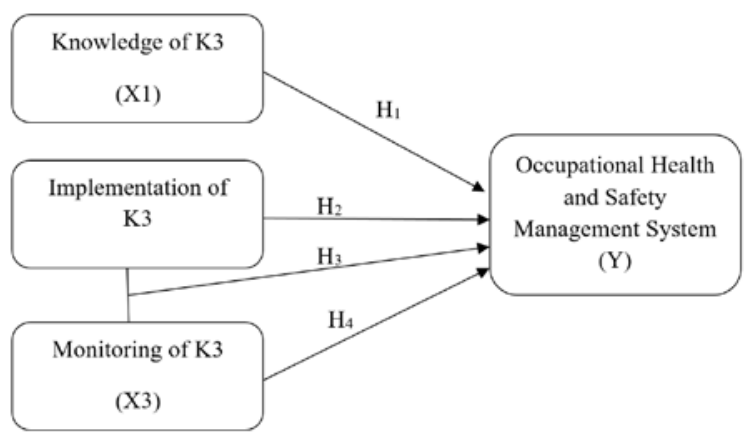

Figure 1. Conceptual Framework 


\section{Hypothesis:}

1. Knowledge (X1) has a positive and significant effect on the Occupational Health and Safety Management System (Y)

2. Implementation of (X2) has a positive and significant effect on the Occupational Health and Safety Management System (Y)

3. Monitoring (X3) has a positive and significant effect on the Occupational Health and Safety Management System (Y)

4. Implementation (X2) and Monitoring (X3) have a positive and significant effect on the Occupational Health and Safety Management System (Y)

\section{RESEARCH METHOD}

This research uses quantitative research methods. The population becomes the object of research, namely the workers of PT. Mujur Lestari with a total of 407 people spread from several divisions and is the latest employee database from the research. The sampling used in this research is a random sampling method or it can be said by simple random sampling and its determination uses the Slovin formula. The number of samples in this study were 81 respondents. In this study, the instrument in this research is a tool to collect data. The tools used are checklist sheets, questionnaire leaflets (open/closed questionnaires), procedures for conducting interviews and cameras to obtain photo documentation.

\section{RESULT AND DISCUSS Multiple Linear Regression Test}

Multiple linear regression analysis was conducted in this study to examine the effect of two or more independent variables (independent) on one dependent variable (dependent). This study analyzes the effect of implementing and monitoring the Occupational Health and Safety Management System (SMK3). Research variables were regressed with the help of the IBM SPSS version 25 application.

Table 2. Multiple Linear Regression Test

\begin{tabular}{|c|c|c|c|c|c|c|}
\hline \multicolumn{7}{|c|}{ Coefficients $^{a}$} \\
\hline \multirow{2}{*}{\multicolumn{2}{|c|}{ Model }} & \multicolumn{2}{|c|}{ Unstandardized Coefficients } & \multirow{2}{*}{$\begin{array}{c}\begin{array}{c}\text { Standardized } \\
\text { Coefficients }\end{array} \\
\text { Beta }\end{array}$} & \multirow[b]{2}{*}{$\mathrm{t}$} & \multirow[b]{2}{*}{ Sig. } \\
\hline & & B & Std. Error & & & \\
\hline \multirow[t]{4}{*}{1} & (Constant) & 15,336 & 6,362 & & 2,411 & 018 \\
\hline & Knowledge &, 080 & , 145 &, 070 & 550 &, 584 \\
\hline & Implementation & ,171 & ,086 & 260 & 2,002 & 049 \\
\hline & Monitoring &, 092 & ,115 &, 089 & ,799 & ,427 \\
\hline
\end{tabular}

\section{Hypotheses test F Test}

This test is intended to determine whether there is an effect of the independent variable together with the dependent variable. This test is also known as the model feasibility test or more popularly referred to as the simultaneous test model.

Table 3. F Test

\begin{tabular}{|c|c|c|c|c|c|c|}
\hline \multicolumn{7}{|c|}{ ANOVA $^{a}$} \\
\hline \multicolumn{2}{|c|}{ Model } & Sum of Squares & df & Mean Square & $\mathrm{F}$ & Sig. \\
\hline \multirow[t]{3}{*}{1} & Regression & 72,075 & 2 & 36,037 & 3,647 &, $031^{\mathrm{b}}$ \\
\hline & Residual & 770,691 & 78 & 9,881 & & \\
\hline & Total & 842,765 & 80 & & & \\
\hline
\end{tabular}

The SPSS output table above shows the $F$ value of $3.647 \mathrm{f}$ table value 0 , and a significance of $0.031<0.05$, it can be concluded that H4 is not accepted, namely the application (X2), and Monitoring (X3) has no significant effect on the Occupational 
Hotbona Novandi Tambunan et.al. Analysis of knowledge, implementation and monitoring of K3 on occupational health and safety management system (SMK3) at Pt. Mujur Lestari Labuhan Batu Selatan.

Health and Safety Management System. (Y).

\section{T Test}

The $\mathrm{T}$ test in multiple linear regression is intended to test whether the parameters (regression coefficients and constants) that are estimated to estimate the multiple linear regression equation/model are the right parameters or not. The exact meaning here is that the parameter is able to explain the behavior of the independent variable in influencing the dependent variable.

Table 4. T Test

\begin{tabular}{|c|c|c|c|c|c|c|}
\hline \multicolumn{7}{|c|}{ Coefficients ${ }^{a}$} \\
\hline \multirow{2}{*}{\multicolumn{2}{|c|}{ Model }} & \multicolumn{2}{|c|}{$\begin{array}{l}\text { Unstandardized } \\
\text { Coefficients }\end{array}$} & \multirow{2}{*}{$\begin{array}{c}\text { Standardized } \\
\text { Coefficients } \\
\text { Beta }\end{array}$} & \multirow[b]{2}{*}{ t } & \multirow[b]{2}{*}{ Sig. } \\
\hline & & \begin{tabular}{l|l} 
B \\
\end{tabular} & Std. Error & & & \\
\hline \multirow[t]{4}{*}{1} & (Constant) & 15.336 & 6.362 & & 2.411 & .018 \\
\hline & Knowladge & .080 & .145 & .070 & .550 & .584 \\
\hline & Implementation & .171 & .086 & .260 & 2,002 & .049 \\
\hline & Monitoring & .092 & .115 & .089 & .799 & .427 \\
\hline
\end{tabular}

1. The value of tcount for the Knowledge variable is 0.550 and table is 0.05 so that tcount $>$ ttable $(0.550>0.05)$. The significance of the knowledge variable on the related variables is 0.584 or greater than the alpha value of 0.025 , so it can be said that the knowledge variable has a significant and significant effect on the Occupational Health and Safety Management System (SMK3) at PT Makmur Lestari

2. The value of tcount for the application variable is 2.002 and table is 0.05 so that tcount $>$ ttable $(2.002>0.05)$. The significance of the Monitoring variable on the related variables is 0.049 or greater than the alpha value of 0.025 . So it can be said that the application variable has a positive and partially significant effect on the Occupational Health and Safety Management System (SMK3) at PT Makmur Lestari

3. The value of the monitoring variable tcount is 0.799 and ttable is 0.05 so that tcount $>$ ttable $(0.779>0.05)$. The significance of the Monitoring variable on the related variables is 0.427 or greater than the alpha value of 0.025 . So it can be said that the Monitoring variable has an effect and is significant on the Occupational Health and Safety Management System (SMK3) at PT Makmur Lestari.

\section{Coefficient of Determination Test $\left(\mathbf{R}^{2}\right)$}

The determinant coefficient shows the ability of the independent variables, namely: Knowledge (X1), Application (X2) and Monitoring (X3), in explaining the dependent variable Occupational Health and Safety Management System (SMK3) (Y) together.

Table 5. Coefficient of Determination Test $\left(\mathbf{R}^{2}\right)$

\begin{tabular}{|l|r|r|r|r|}
\hline \multicolumn{6}{|c|}{ Model Summary } \\
\hline Model & R & R Square & $\begin{array}{c}\text { Adjusted R } \\
\text { Square }\end{array}$ & $\begin{array}{c}\text { Std. Error of the } \\
\text { Estimate }\end{array}$ \\
\hline 1 & $.299^{3}$ &, 089 &, 054 & 3,157 \\
\hline a. Predictors: (Constant), Monitoring, Knowladge, Implementation \\
\hline
\end{tabular}

The R-Square value of 0.89 , it shows that the proportion of the influence of knowledge, application and Monitoring variables on the Occupational Health and Safety Management System (SMK3) variable is $89 \%$. This means that knowledge, application and Monitoring in the Occupational Health and Safety Management System (SMK3) PT. Mujur Lestari has a proportion of influence on the Occupational Health and Safety Management System (SMK3) PT. Mujur Lestari is $89 \%$ while the remaining $11 \%$ $(100 \%-89 \%)$ is influenced by other variables that are not in this linear regression model. The impact caused by the implementation and Monitoring of the Occupational Health and Safety Management System (SMK3), which contributed a value of $89 \%$, was large.

\section{CONCLUSION}

1. Knowledge has a significant and positive influence on the Occupational Health and Safety Management System (SMK3)

2. The application has a positive and significant impact on the Occupational 
Hotbona Novandi Tambunan et.al. Analysis of knowledge, implementation and monitoring of K3 on occupational health and safety management system (SMK3) at Pt. Mujur Lestari Labuhan Batu Selatan.

Health and Safety Management System (SMK3).

3. Monitoring also has a positive and significant impact on the Occupational Health and Safety Management System (SMK3).

4. Implementation and Monitoring is unacceptable and insignificant to the Occupational Health and Safety Management System (SMK3).

\section{Conflict of Interest: None}

\section{REFERENCES}

1. Ahmad Tanzeh. (2011). Metode Penelitian Praktis. Yogyakarta: Teras.

2. Andi Lala. (2018). Pengawasan Kesehatan Tenaga Kerja Menurut PP Nomor 50 Tahun 2012 Tentang Penerapan SMK3. Syntax Literate: Jurnal Ilmiah Indonesia. Vol. 3, No. $12,1-12$

3. Angga Sony Armindo Marpaung. (2018). Pelaksanaan Fungsi Pengawasan Sistem Manajemen Keselamatan dan Kesehatan Kerja (SMK3) Dalam Menekan Angka Kecelakaan Kerja di Kabupaten Deli Serdang (Studi Kasus PT. Suryamas Lestari Prima Kecamatan Tanjung Morawa). Tesis. Magister Studi Pembangunan Fakultas Ilmu Sosial Dan Ilmu Politik Universitas Sumatera Utara Medan.

4. Anggraini, J. (2012). Hukum Administrasi Negara. Yogyakarta: Graha Ilmu.

5. Anita, O. I. (2015). Pengawasan Pemerintah Terhadap Penerapan Sistem Manajemen Keselamatan dan Kesehatan Kerja (SMK3) Kabupaten Temanggung.

6. Arikunto, S. (2013). Prosedur Penelitian Suatu Pendekatan Praktik. Edisi Revisi. Jakarta: PT. Rineka Cipta

7. Dina Lusiana Setyowati, Diana Pratiwi dan M. Sultan (2018). Hubungan Pengetahuan, Sikap, Pelatihan, Pengawasan dengan Persepsi Tentang Penerapan SMK3. ISSN 2088-673X | e-ISSN 2597-866.

8. Farida Noviana. (2011). Artikel Kesehatan, Keselamatan, dan Keamanan Kerja http://faridanoviana.blog.perbanas.ac.id/201 1/12/04/artikel-kesehatan-keselamatandankeamanan-kerja/

9. Febyana Pangkey dan Grace Y. Malingkas, D. W. (2012, Juli). Penerapan Sistem Manajemen Keselamatan dan Kesehatan
Kerja (SMK3) pada Proyek Konstruksi di Indonesia (Studi Kasus: Pembangunan Jembatan Dr. Ir. Soekarno-Manado). Jurnal Ilmiah Media Engineering, Vol. 2, No. 2, 100-113 dari https://media.neliti.com/media/publications/9 7452-ID-penerapan-sistem-manajemenkeselamatan-d.pdf

10. Ghozali, I. (2011). Aplikasi Analisis Multivariate dengan Program SPSS. Semarang: UNDIP.

11. Haris Herdiansyah. (2010). Metodologi Penelitian Kualitatif. Jakarta: Salemba Humanika.

12. ISO. ISO 45001 Occupational health and safety. https://www.iso.org/iso-45001occupational-health-and-safety.htmlISO

Manajemen. Pengertian dan Manfaat Penerapan Sistem Manajemen K3

13. Iraj Mohammadfam, Mojtaba Kamalinia, Mansour Momeni, Rostam Golmohammadi, Yadollah Hamidi dan Alireza Soltanian (2016). Developing An Integrated Decision Making Approach To Assess Andpromote The Effectiveness Of Occupational Health And Safety management Systems. Journal of Cleaner Production. Vol. 127 119-133

14. Irvan Suryadi, M. R. (2019). Sistem Manajemen Keselamatan dan Kesehatan Kerja (SMK3). Lampung: Institut Teknologi Sumatera.

15. Kwesi Amponsah-Tawiah dan Justice Mensah. (2016). Occupational Health and Safety and Organizational Commitment:Evidence from the Ghanaian Mining Industry. Safety and Health at Work. Vol.7, p. 225-230

16. Lusia Salmawati, S. D. (2015, Maret). Hubungan Penerapan Sistem Manajemen Keselamatan dan Kesehatan Kerja dengan Motivasi Kerja dan Stres Kerja Pada Perawat di Rumah Sakit Umum Anutapura Palu. Jurnal Manajemen Pelayanan Kesehatan, Vol. 18, No. 1, 4-6. dari https://jurnal.ugm.ac.id/jmpk/article/viewFil e/5770/15698

17. Milen, A. E. (2016). Analisis Level Keselamatan dan Kesehatan Kerja (K3) Proyek Konstruksi Terhadap Resiko dan Manajemen K3.

18. Mulyadi. (2015). Manajemen Sumber Daya Manusia (MSDM). Bogor: In Media. 
Hotbona Novandi Tambunan et.al. Analysis of knowledge, implementation and monitoring of K3 on occupational health and safety management system (SMK3) at Pt. Mujur Lestari Labuhan Batu Selatan.

19. Murhaini, S. (2014). Manajemen Pengawasan Pemerintahan Daerah. Yogyakarta: Pustaka Pelajar.

20. Notoatmodjo S. (2010). Ilmu Perilaku Kesehatan. Jakarta: Rineka Cipta

21. Priyanti, S. (2011). Pengaruh Pengetahuan Terhadap Sikap. Mojokorto: Hospital Majapahit.

22. Rini, W. S. (2013). Penerapan Sistem Manajemen Keselamatan dan Kesehatan Kerja (K3) dan Identifikasi Potensi Bahaya Kerja (Studi Kasus di PT. LTX Kota Cilegon- Banten). Spektrum Industri, Vol. 11, No. 2,, 117-242 dari http://journal.uad.ac.id/index.php/Spektrum/ article/view/1663/1161

23. R.N Asih \& Y. Latief. (2020). Evaluation of Implementation Within Occupational Health and Safety Management System Based on Indonesia Government Regulation Number 50 of 2012 and ISO 45001:2018 (Case Study: Company X). Advances in Health Sciences Research. Vol. 34, p. 274-279.

24. Robbins, Stephen P. 2006. Perilaku Organisasi. PT Indeks Kelompok Gramedia: Jakarta.

25. Silvana Sidauruk, Adi Heru Sutomo dan Hendarto Budiyono.(2016). Komitmen Manajemen, Pengetahuan K3 dan Sikap K3 dengan Penerapan SMK3 kepada Pekerja.

26. Setyoko (2017, November). Sistem Manajemen Keselamatan dan Kesehatan Kerja (SMK3) pada Perusahaan. Orbith,
Vol. 13 No. 3, 172-177 dari https://jurnal.polines.ac.id/index.php/orbith/ article/view/1143

27. Soedarjadi. (2009). Hak dan Kewajiban Pekerja Pengusaha. Yogyakarta: Pustaka Yustisia.

28. Sugiyono. (2018). Metode Penelitian Kombinasi (Mixed Methods). Bandung: CV Alfabeta.

29. Transmigrasi, M. T. (t.thn.). Peraturan Menteri Tenaga Kerja dan Transmigrasi. Permenaker No. 05/Men/1996 Tentang Sistem Manajemen Keselamatan dan Kesehatan Kerja.

30. Wahab. (2008). Tujuan Penerapan Program. Jakarta: Bulan Bintang.

31. Yahya, Y. (2006). Pengantar Manajemen. Yogyakarta: Graha Ilmu.

32. Yanti, H. (2004). Mekanisme Pengawasan Terhadap Peraturan Daerah Menurut Undang-Undang Nomor 32 Tahun 2004.

33. Zain, B. d. (2010). Efektifitas Bahasa Indonesia. Jakarta: Balai Pustaka

How to cite this article: Hotbona Novandi Tambunan, Nazaruddin, Isfenti Sadalia. Analysis of knowledge, implementation and monitoring of $\mathrm{K} 3$ on occupational health and safety management system (SMK3) at Pt. Mujur Lestari Labuhan Batu Selatan. International Journal of Research and Review. 2021; 8(12): 404-410. DOI: https://doi.org/10.52403/ijrr. 20211249 